ISSN 0258-7122

Bangladesh J. Agril. Res. 34(3) : 493-503, September 2009

\title{
GENETIC DIVERSITY ANALYSIS IN BRASSICA VARIETIES THROUGH RAPD MARKERS
}

\author{
K. K. GHOSH, M. E. HAQUE ${ }^{1}$, Ms. S. PARVIN ${ }^{2}$ \\ F. AKHTER AND M. M. RAHIM
}

\begin{abstract}
This investigation was aimed at exploring the genetic diversity and relationship among nine Brassica varieties, namely BARI Sharisha-12, Agrani, Sampad, BINA Sharisha-4, BINA Sharisha-5, BARI Sharisha-13, Daulot, Rai-5, Alboglabra using Random Amplified Polymorphic DNA (RAPD) markers. In total, 59 reproducible DNA bands were generated by four arbitrary selected primers of which 58 (98.03\%) bands were proved to be polymorphic. These bands ranged from 212 to 30686 bp in size. The highest proportion of polymorphic loci and gene diversity values were $37.29 \%$ and 0.1373 , respectively, for BARI Sharisha-12 and the lowest proportion of polymorphic loci and gene diversity values were $8.47 \%$ and $0.0318,8.47 \%$ and 0.0382 for BINA Sharisha-4 and Rai-5, respectively. A dendrogram was constructed using unweighted pair group method of arithmetic mean (UPGMA). The result of cluster analysis indicated that the 9 accessions were capable of being classified into 2 major groups. One group consists of BARI Sharisha-12, Agrani, Sampad, Daulot, Rai-5, Alboglabra. where Daulot and Rai-5 showed the lowest genetic distance of 0.049. And another group contains BINA Sharisha-4, BINA Sharisha-5, and BARI Sharisha-1 3, where BINA Sharisha-5 and BARI sharisha-13 showed genetic distance of 0.071 .
\end{abstract}

Key Words: RAPD, Brassica, genetic distance, polymorphic band.

\section{Introduction}

Crops of the genus Brassica are widely used in the cuisine of many cultures to the many choices of edible forms in the genus. Economically, Brassica is loosely categorized into oilseed, vegetable, and condiment crops. Among the Brassica species, the varieties of $B$. nigra, $B$. carinata, and $B$. juncea are commonly known as mustard, while those of $B$. campestris and B. napus as rapeseed (Yarnell, 1956). B. oleracea is known as cole crop which includes two major groups, the vegetable and the oilseed group. Assessment of genetic variability is the first step in any crop improvement programme. Molecular techniques viz., Restriction fragment length

Research Fellow, BAU, Mymensingh-2202. ' Scientific officer, Biotechnology Division, BARI, Joydebpur, Gazipur-1701, '2Scientific Officer, Plant Breeding Division, BARI, .Joydebpur, Gazipur-1701, Babgladesh. 
polymorphism (RFLP), Simple sequence repeats (SSR), Random amplification of polymorphic DNA (RAPD) (Williams et al., 1990) and the recently developed Amplified fragment length polymorphism (AFLP) (Vos et al., 1995) are the modern tools for precise estimation of genetic variation in crop species. Among them, RAPD markers, generated by the polymerase chain reaction (PCR) has widely been used since 1990s to assess intra specific genetic variation at molecular level (William et al., 1990). The technique of RAPD gained importance due to its simplicity, efficiency, relative ease to perform and non-requirement of sequence information. It is, therefore, the aim of this work is to provide genetic variation and relatedness of some Brassica varieties by PCR based RAPD technique, as it is important, particularly for selection of diverse parents to be used in hybridization programme.

\section{Materials and Method}

Nine varieties of Brassica spp. viz., BARI Sharisha-12, Agrany, Sampad, BINA Sharisha-4, BINA Sharisha-5, BARI Sharisha-13, Daulot, Rai-5, Alboglabra were used in the study. Out of the nine varieties, three were BINA varieties (Agrany, BINA Sharisha-4, and BINA Sharisha-5), four BARI varieties (BARI Sharisha-12, BARI Sharisha-13, Daulot, and Rai-5), one was BAU variety (Sampad) and Alboglabra was exotic line from Germany. Seed germination was performed in the laboratory and the germinated seeds were sown in the pot placed in the green house of the Department of Genetics and Plant Breeding of Bangladesh Agricultural University. Fresh and young leaf samples were collected from 12-day old seedlings. Genomic DNA was extracted from young leaf following Phenol: Chloroform: Isoamyl alcohol (25:24:1; v:v:v) purification and ethanol precipitation method. DNA was precipitated with $800 \mu 1$ of absolute ethanol where DNA became visible as white strands by flicking the tube several times with fingers. DNA was pelleted by centrifugation and reprecipitation of the DNA solution was done by adding $400 \mu \mathrm{l}$ of $70 \%$ ethanol. The pellets were then air dried and dissolved in $50 \mu 1$ of TE buffer (10mM Tris. HC1, 1 mM EDTA, pH=8.0). DNA quality was checked by electrophoresis in $2.5 \%$ agarose gel and quantified (Table 1) using a spectrophotometer at $260 \mathrm{~nm}$ wave length (Spectronic $^{\circledR}$ GENESIS ${ }^{\mathrm{TM}}$ ). The DNA samples were evaluated both quantitatively and qualitatively using spectrophotometer and agarose gel electrophoresis, respectively. 
Table 1. Absorbance readings and concentrations of different DNA samples.

\begin{tabular}{|c|c|c|c|}
\hline Brassica variety & Serial No. & $\begin{array}{l}\text { Absorbance reading } \\
\text { (at } 260 \mathrm{~mm} \text { ) }\end{array}$ & $\begin{array}{l}\text { DNA concentration } \\
(\mathrm{ng} / \mu \mathrm{l})\end{array}$ \\
\hline \multirow[t]{3}{*}{ BARI Sharisha-12 } & $\mathrm{B}_{1-1}$ & 0.038 & 1900 \\
\hline & $\mathrm{B}_{1-2}$ & 0.047 & 2350 \\
\hline & $\mathrm{B}_{1-3}$ & 0.034 & 1700 \\
\hline \multirow[t]{3}{*}{ Agrani } & $\mathrm{B}_{2-1}$ & 0.013 & 650 \\
\hline & $\mathrm{B}_{2-2}$ & 0.018 & 900 \\
\hline & $\mathrm{B}_{2-3}$ & 0.016 & 800 \\
\hline \multirow[t]{3}{*}{ Sampad } & $\mathrm{B}_{3-1}$ & 0.012 & 600 \\
\hline & $\mathrm{B}_{3-2}$ & 0.009 & 450 \\
\hline & $\mathrm{B}_{3-3}$ & 0.014 & 700 \\
\hline \multirow[t]{3}{*}{ BINA Sharisha-4 } & $\mathrm{B}_{4-1}$ & 0.025 & 1250 \\
\hline & $\mathrm{B}_{4-2}$ & 0.020 & 1000 \\
\hline & $\mathrm{B}_{4-3}$ & 0.018 & 900 \\
\hline \multirow[t]{3}{*}{ BINA Sharisha-5 } & $\mathrm{B}_{5-1}$ & 0.010 & 500 \\
\hline & $\mathrm{B}_{5-2}$ & 0.009 & 450 \\
\hline & $\mathrm{B}_{5-3}$ & 0.036 & 1800 \\
\hline \multirow[t]{3}{*}{ BARI Sharisha-13 } & $\mathrm{B}_{6-1}$ & 0.083 & 4150 \\
\hline & $\mathrm{B}_{6-2}$ & 0.036 & 1800 \\
\hline & $\mathrm{B}_{6-3}$ & 0.003 & 150 \\
\hline \multirow[t]{3}{*}{ Daulot } & $\mathrm{B}_{7-1}$ & 0.057 & 2850 \\
\hline & $\mathrm{B}_{7-2}$ & 0.038 & 1900 \\
\hline & $\mathrm{B}_{7-3}$ & 0.024 & 1200 \\
\hline \multirow[t]{3}{*}{ Rai-5 } & $B_{8-1}$ & 0.042 & 2100 \\
\hline & $\mathrm{B}_{8-2}$ & 0.021 & 1050 \\
\hline & $\mathrm{B}_{8-3}$ & 0.028 & 1400 \\
\hline \multirow[t]{3}{*}{ Alboglabra } & $\mathrm{B}_{9-1}$ & 0.021 & 1050 \\
\hline & $\mathrm{B}_{9-2}$ & 0.028 & 1400 \\
\hline & $\mathrm{B}_{9-3}$ & 0.022 & 1100 \\
\hline
\end{tabular}

Table 2. RAPD primers with corresponding bands scored polymorphic bands observed in nine Brassica varieties.

\begin{tabular}{l|l|l|l|c}
\hline Primer codes & Sequences $\left(5^{\prime}-3^{\prime}\right)$ & $\begin{array}{c}\text { Total no. of } \\
\text { bands scored }\end{array}$ & Size range (bp) & $\begin{array}{c}\text { No. of } \\
\text { polymorphic } \\
\text { bands }\end{array}$ \\
\hline OPB-04 & GGACTGGAGT & 11 & $300-1929$ & 10 \\
OPC-05 & GATGACCGCC & 19 & $376-3068$ & 19 \\
OPC-09 & CTCACCGTCC & 14 & $212-2034$ & 14 \\
OPD-02 & GGACCCAACC & 15 & $396-2272$ & 15 \\
\hline Total & 59 & & 58 \\
\hline
\end{tabular}

The primers used in RAPD analysis were found to discriminate different varieties and single exotic line (Two randomly chosen individuals from two different varieties to evaluate their suitability for amplification of the DNA 
sequences) effectively. Among the 14 primers (Table 3) initially tested, 4 primers (OPB-04, OPC-05, OPC-09, and OPD-02) yielded comparatively maximum number of amplification products with high intensity and minimal smearing, good resolution and also clear bands. The number of fragments amplified per primer varied (Table 2).

Table 3. Parameters of the Operon random primers used in the present study for screening.

\begin{tabular}{|c|c|c|c|}
\hline $\begin{array}{l}\text { Primer } \\
\text { Code }\end{array}$ & Sequences $\left(5^{\prime}-3^{\prime}\right)$ & $\begin{array}{c}\text { GC content } \\
(\%)\end{array}$ & Reference \\
\hline OPA-02 & TGCCGAGCTG & 70 & Jain et al. (1994) and Cartea et al. (2005) \\
\hline OPA-05 & AGGGGTCTTG & 60 & Jain et al. (1994) and Cartea et al. (2005) \\
\hline OPA-07 & GAAACGGGTG & 60 & Jain et al. (1994) and Cartea et al. (2005) \\
\hline OPA-09 & GGGTAACGCC & 70 & Jain et al. (1994) and Cartea et al. (2005) \\
\hline OPB-03 & CATCCCCFTG & 60 & Cartea et al. (2005) \\
\hline OPB-04* & GGACTGGAGT & 60 & Cartea et al. (2005) \\
\hline OPB-05 & TGCGCCCTTC & 70 & Cartea et al. (2005) \\
\hline OPB-10 & CTGCTGGGAC & 70 & Cartea et al. (2005) \\
\hline OPC-05* & GATGACCGCC & 70 & Jain et al. (1994) and Cartea et al. (2005) \\
\hline OPC-09* & CTCACCGTCC & 70 & Jain et al. (1994) and Cartea et al. (2005) \\
\hline OPD-02* & GGACCCAACC & 70 & Cartea et al. (2005) \\
\hline OPK-10 & GTGCAACGTG & 60 & Rabbani et al. (1998) \\
\hline OPL-07 & AGGCGGGAAC & 70 & Rabbani et al. (1998) \\
\hline OPL-14 & GTGACAGGCT & 60 & Rabbani et al. (1998) \\
\hline
\end{tabular}

* Selected for RAPD analysis for all samples of the nine varieties

\section{DNA amplification by PCR and clectrophoresis}

PCR reactions were performed on each DNA sample in a $10 \mu \mathrm{l}$ reaction mix containing $1.0 \mu \mathrm{l}$ of 10x Ampli Taq polymerase buffer, $2.5 \mu \mathrm{l}$ primer, $1.0 \mu \mathrm{l}$ dNTPs, $0.2 \mu 1$ Ampli Taq DNA polymerase (Genei Pvt. Ltd., Bangalore, India) and $4.0 \mu 1$ of genomic DNA and $1.3 \mu 1$ sterile deionized water. DNA amplification was performed in an oil-free thermal cycler (Master Cycler Gradient, Eppendorf, Germany). The reaction mix was preheated at $95^{\circ} \mathrm{C}$ for 3 $\mathrm{mm}$ followed by 40 cycles of 1 min denaturation at $94^{\circ} \mathrm{C}, 1 \mathrm{~min}$ annealing at $36^{\circ} \mathrm{C}$ and extension at $72^{\circ} \mathrm{C}$ for $2 \mathrm{~min}$. After the last cycle, a final step of $7 \mathrm{~mm}$ at $72^{\circ} \mathrm{C}$ was added to allow complete extension of all amplified fragments. 

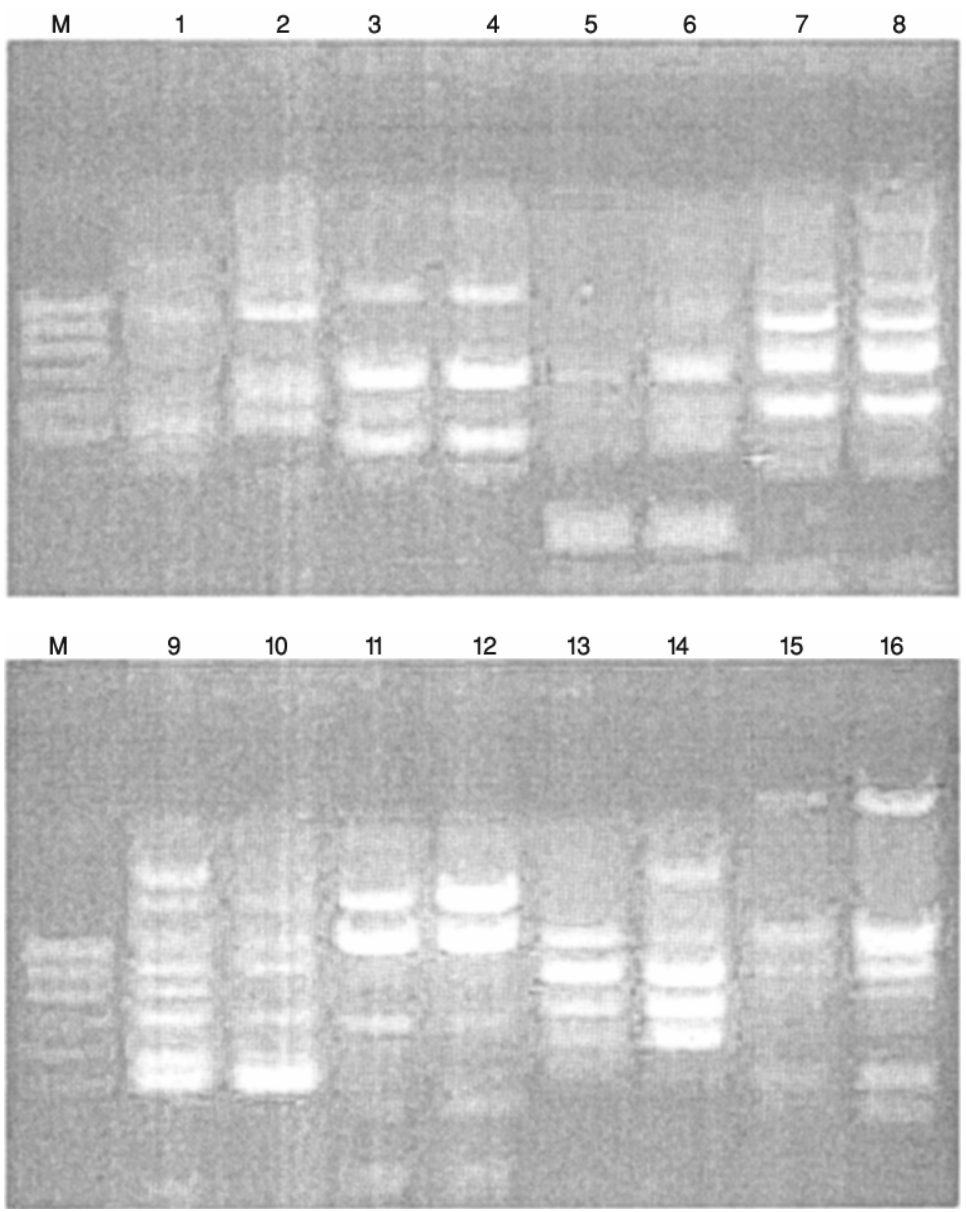

Fig. 1. Primer section PCR amplification products directed by 14 different decamer random primers using DNA from two randomly chosen individuals from different Brassica varieties Lane 1-2; OPA-02 Lane 3-4 OPA-07, Lane 5-6; OPA-09 Lane 7-8 OPB-04 Lane 9-10 OPB-05, Lane 11-12 OPC-05, Lane 13-14; OPC-09, Lane 15-16, OPD -02, M. Molecular weight marker (100 bp DNA ladder).

The amplified product from each sample was separated electrophoretically on 2.5\% agarose gel containing ethidium bromide (SRL, India) in lx TBE buffer. A molecular weight DNA marker (100 bp DNA ladder) was loaded in the first lane of the gel. Electophoresis was carried out at $83 \mathrm{v}$ for $50 \mathrm{~min}$ to get the dye 3/4 of the gel length. DNA bands were observed on UV-transilluminator in the dark chamber of the Image Documentation System (uvitec, UK) and the image was viewed on the monitor, focused, acquired, saved and printed on thermal paper. 


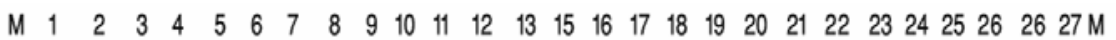

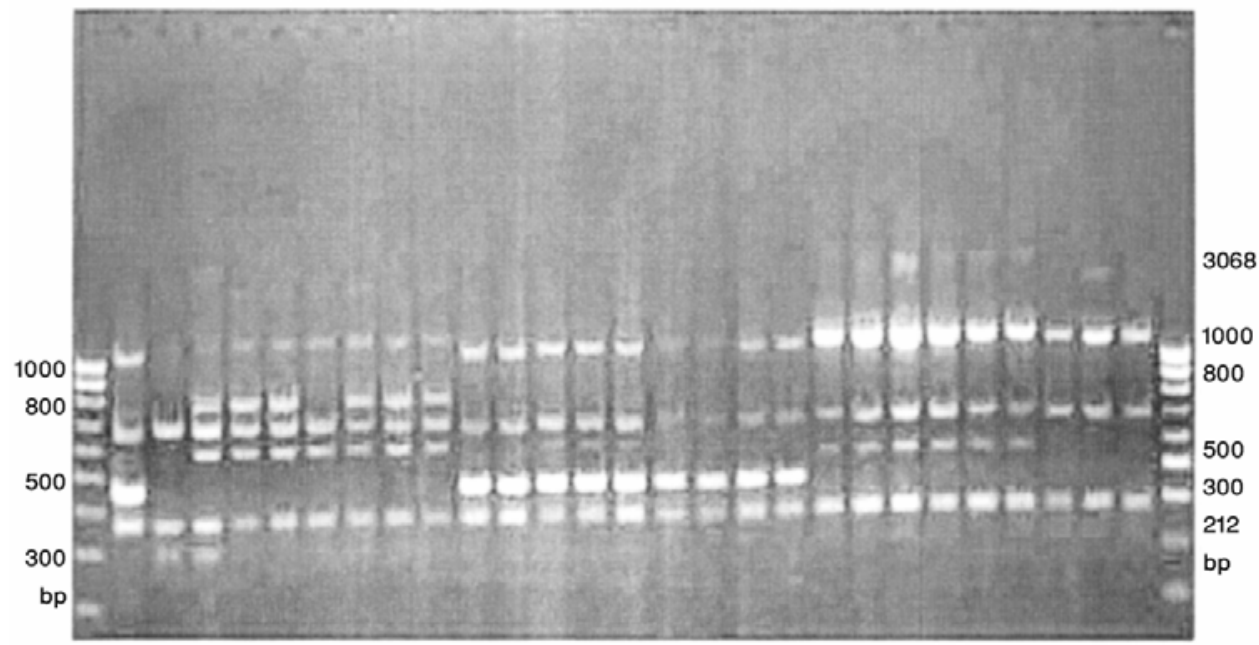

Fig. 2. RAPD profiles of nine Brassica varieties using primer OPB-04 Lane 1-2 BARI Sharisha-12, Lane 4-6 Agrani Lane 7-9, Sampad Lane 12-12 BINA Sharisha-4, 13-16 BINA Sharisha-5, Lane 16-18, BINA Sharisha-13 Lane 19-21, Daulot Lane 22-24, Rai-5, Lane 25-27, Alboglabra M Molecular weight marker (100 bp DNA ladder in both sides).

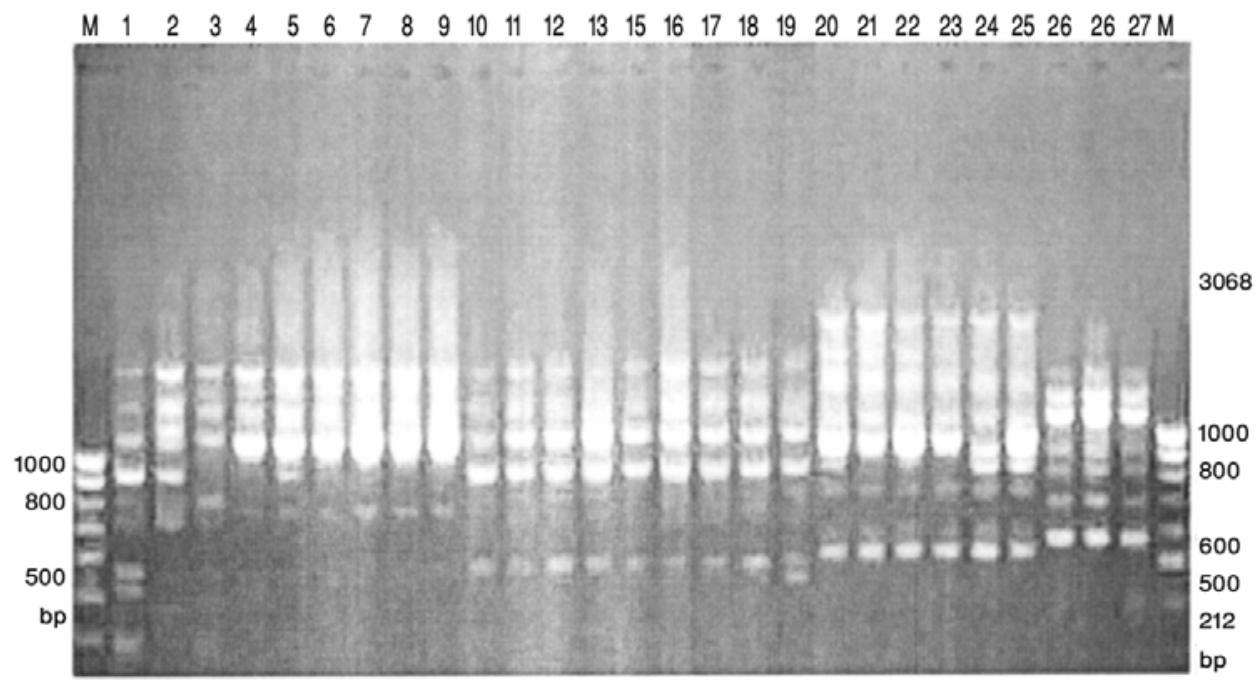

Fig. 3. RAPD profiles of nine Brassica varieties using primer OPC-05 Lane 1-2 BARI sharisha-12, Lane 4-6 Agrani Lane 7-9, Sampad Lane 10-12 BINA Sharisha-4 1315 BINA Sharisha-5, Lane 16-18, BINA Sharisha-13 Lane 19-21 Daulot Lane 2224 Rai-5, Lane 25-27, Alboglabra, M Molecular weight marker (100 bp DNA ladder in both sides). 


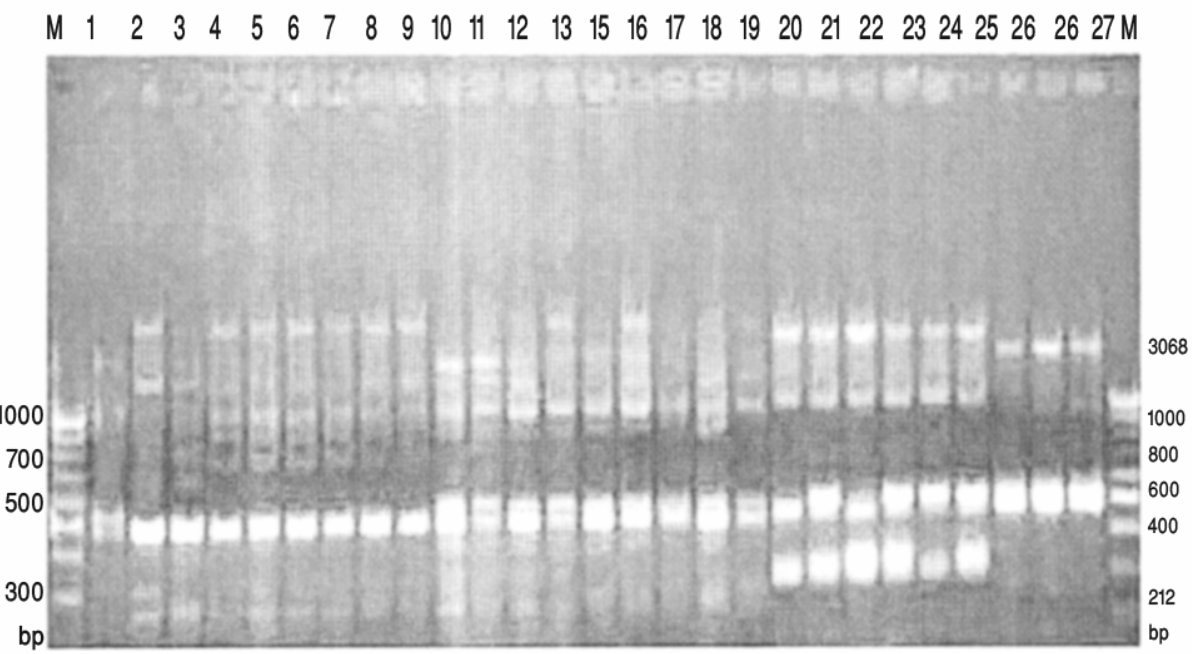

Fig. 4. RAPD profiles of nine Brassica varieties using primer OPC-09 Lane 1-2 BARI sharisha-12, Lane 4-6 Agrani Lane 7-9, Sampad Lane 10-12 BINA Sharisha-4 1315 BINA Sharisha-5, Lane 16-18, BINA Sharisha-13 Lane 19-21 Daulot Lane 2224 Rai-5, Lane 25-27, Alboglabra, M Molecular weight marker (100 bp DNA ladder in both sides).

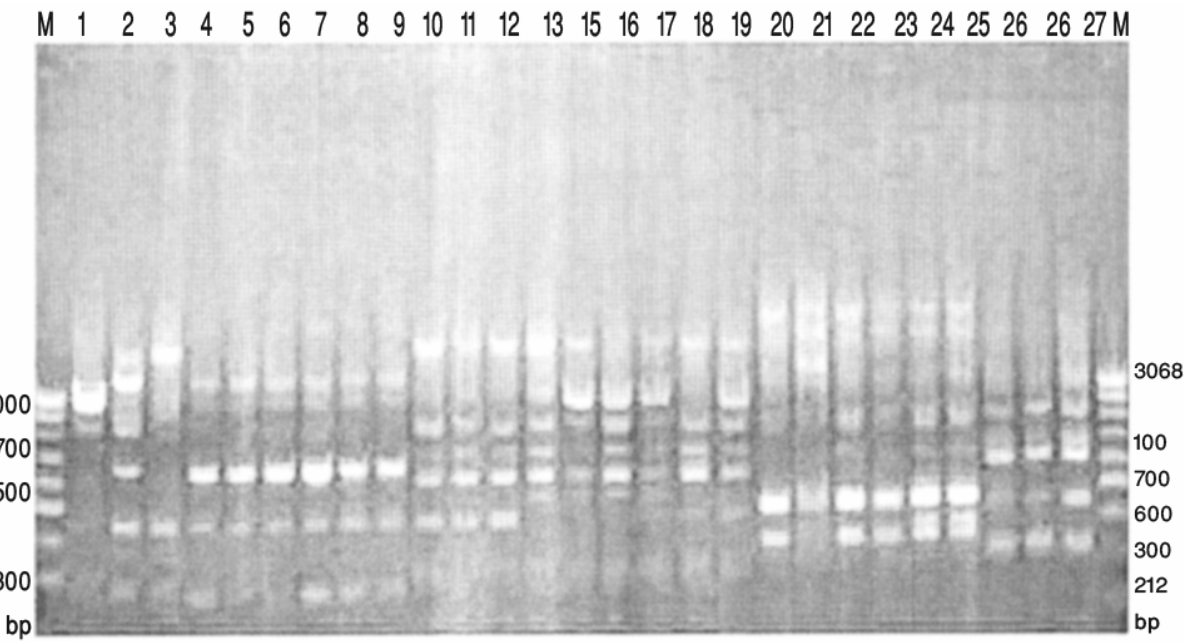

Fig. 5. RAPD profiles of nine Brassica varieties using primer OPD-02 Lane 1-2 BARI sharisha-12, Lane 4-6 Agrani Lane 7-9, Sampad Lane 10-12 BINA Sharisha-4 1315 BINA Sharisha-5, Lane 16-18, BINA Sharisha-13 Lane 19-21 Daulot Lane 2224 Rai-5, Lane 25-27, Alboglabra, M Molecular weight marker (100 bp DNA ladder in both sides). 


\section{RAPD data analysis}

All distinct bands or fragments (RAPD markers) were thereby given identification numbers according to their position on gel and scored visually on the basis of their presence (1) or absence (0), separately for each individual and each primer. The scores obtained using all primers in the RAPD analysis were then pooled to create a single data matrix. This was used to estimate polymorphic loci (Neis, 1973), gene diversity, population differentiation $\left(G_{s t}\right)$, gene flow $\left(N_{m}\right)$, genetic distance (D) and to construct a UPGMA (Unweighted Pair Group Method of Arithmetic Means) dendrogram among populations using a computer programme, POPGENE (Version 1.31) (Yeh et al., 1999).

\section{Results and Discussion}

The highest number and proportion of polymorphic loci was found in the variety of BARI Sharisha-12, which were 22 and 37.29\%, respectively, whereas the lowest values of these traits was recorded in both the varieties of BINA Sharisha4 and Rai-5 (Table 4). However, the highest and lowest Nei's (1973) gene diversity values were found in BARI Sharisha-12 and BINA Sharisha-4, respectively.

Table 4. Number and proportion of polymorphic bands, gene diversity obtained in different Brassica species.

\begin{tabular}{l|l|l|l}
\hline \multicolumn{1}{c|}{ Variety } & \multicolumn{1}{c|}{$\begin{array}{c}\text { No. of } \\
\text { polymorphic } \\
\text { loci }\end{array}$} & $\begin{array}{c}\text { Proportion of } \\
\text { polymorphic } \\
\text { loci (\%) }\end{array}$ & Gene diversity \\
\hline 1. BARI Sharisha-12 & 22 & 37.29 & 0.1373 \\
2. Agrani & 12 & 20.34 & 0.0865 \\
3. Sampad & 7 & 11.86 & 0.0547 \\
4. BINA Sharisha-4 & 5 & 8.47 & 0.0318 \\
5. BINA Sharisha-5 & 12 & 20.34 & 0.0833 \\
6. BARI Sharisha-13 & 14 & 23.73 & 0.0966 \\
7. Daulot & 9 & 15.25 & 0.0617 \\
8. Rai-5 & 5 & 8.47 & 0.0382 \\
9. Alboglabra & 14 & 23.73 & 0.0871 \\
\hline
\end{tabular}

Table 5. presented the pair-wise gene flow $\left(\mathrm{N}_{\mathrm{m}}\right)$ values. The highest gene flow $\left(\mathrm{N}_{\mathrm{m}}\right)$ values was found in BINA Sharisha-5 - BARI Sharisha-13 varietals pair which was 1.45. On the other hand, the lowest gene flow value (0.07) was observed in BINA Sharisha-4 - Rai-5 (Table 5). 
Table 5. Gene flow value $\left(\mathrm{N}_{\mathrm{m}}\right)$ in different varietal pair (below diagonal.

\begin{tabular}{l|l|l|l|l|l|l|l|l}
\hline \multicolumn{1}{c|}{ Variety } & $\begin{array}{c}\text { BARI } \\
\text { Sharishs-12 }\end{array}$ & Agrani & Sampad & $\begin{array}{c}\text { BINA } \\
\text { Sharishs-4 }\end{array}$ & $\begin{array}{c}\text { BINA } \\
\text { Sharishs-5 }\end{array}$ & $\begin{array}{c}\text { BARI } \\
\text { Sharishs-13 }\end{array}$ & Daulot & Rai-5 \\
\hline Agrani & 0.59 & & & & & & \\
Sampad & 0.42 & 1.09 & & & & & \\
BINA & 0.31 & 0.13 & 0.09 & & & & & \\
Sharishs-4 & & & & & & & & \\
BINA & 0.54 & 0.22 & 0.13 & 0.51 & & & & \\
Sharishs-5 & & & & & & & & \\
BARI & 0.76 & 0.28 & .21 & 0.49 & 1.45 & & & \\
Sharishs-13 & & & & & & & & \\
Daulot & 0.33 & 0.22 & 0.17 & 0.09 & 0.17 & 0.22 & \\
Rai-5 & 0.26 & 0.17 & 0.12 & 0.07 & 0.14 & 0.18 & 1.10 & \\
Alboglabra & 0.48 & 0.25 & 0.19 & 0.14 & 0.28 & 0.34 & 0.25 & 0.24 \\
\hline
\end{tabular}

The highest Nei's (1972) genetic distance (0.768) was observed in BINA Sharisha-4 - Rai-5 varietals pair whereas, the lowest genetic distance (0.049) was estimated in Daulot — Rai-5 varietals pair (Table 6). Furthermore, high level of genetic distance was found in BINA Sharisha-4-Daulot (0.764); Sampad-BINA Sharisha-4 (0.722) varietals pair and low level of genetic distance was observed in Agrani-Sampad (0.071), BINA Sharisha-5-BARI Sharisha-13 (0.071) varietals pair (Table 6).

Table 6. Summary of Nei's (1972) genetic distance (below diagonal) values between nine Brassica varieties.

\begin{tabular}{|c|c|c|c|c|c|c|c|c|}
\hline Variety & $\begin{array}{c}\text { BARI } \\
\text { Sharishs-12 }\end{array}$ & Agrani & Sampad & $\begin{array}{c}\text { BINA } \\
\text { Sharishs-4 }\end{array}$ & $\begin{array}{c}\text { BINA } \\
\text { Sharishs-5 }\end{array}$ & $\begin{array}{c}\text { BARI } \\
\text { Sharishs-13 }\end{array}$ & Daulot & Rai-5 \\
\hline Agrani & 0.23 & & & & & & & \\
\hline Sampad & 0.293 & 0.071 & & & & & & \\
\hline $\begin{array}{l}\text { BINA } \\
\text { Sharishs-4 }\end{array}$ & 0.356 & 0.672 & 0.722 & & & & & \\
\hline $\begin{array}{l}\text { BINA } \\
\text { Sharishs-5 }\end{array}$ & 0.261 & 0.556 & 0.613 & 0.126 & & & & \\
\hline $\begin{array}{l}\text { BARI } \\
\text { Sharishs-13 }\end{array}$ & 0.189 & 0.447 & 0.483 & 0.150 & 0.071 & & & \\
\hline Daulot & 0.411 & 0.450 & 0.438 & 0.764 & 0.614 & 0.506 & & \\
\hline Rai-5 & 0.461 & 0.495 & 0.490 & 0.768 & 0.598 & 0.528 & 0.049 & \\
\hline Alboglabra & 0.307 & 0.473 & 0.487 & 0.579 & 0.403 & 0.354 & 0.394 & 0.332 \\
\hline
\end{tabular}

Based on Nei's (1972) genetic distance using Unweighted Pair Group Method of Arithmetic Mean (UPGMA), the 9 accessions were segregated into two major clusters (Fig. 6). As a result, BARI Sharisha-12, Agrani, Sampad, Daulot, Rai-5, Alboglabra clustered into one group that had two sub-clusters.BARI Sharisha-12, 
Agrani, and Sampad were grouped in sub-cluster I and Daulot, Rai-5, Alboglabra were grouped in sub-cluster II. In sub-cluster I, Agrani and Sampad showed closer relationship with minimal genetic distance $(0.071)$ and in sub-cluster II. Daulot and Rai-5 showed closer relationship with lowest genetic distance (0.049). BINA Sharisha-4, BINA Sharisha-5 and BARI Sharisha-13 clustered into another group where BINA Sharisha-5, and BARI Sharisha-13 showed closer relationship with minimal genetic distance (0.071).

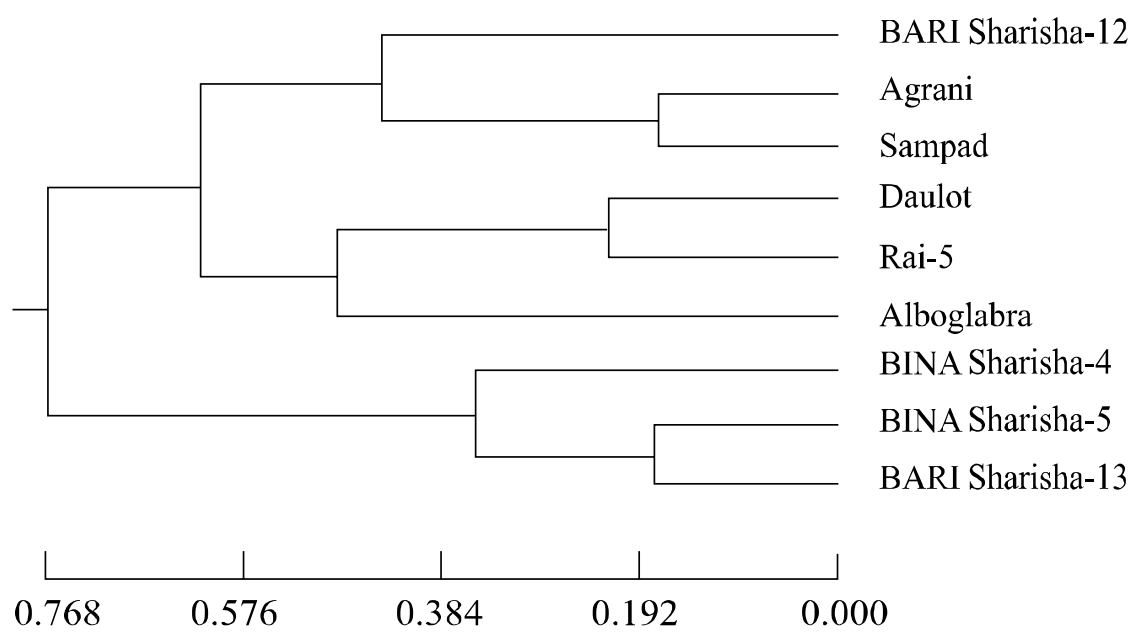

Fig. 6. UPGMA dendrogram based on Nei's (1972) genetic distance, summarizing the data on differentiation between nine Brassica varieties according to RAPD analysis.

The information can be used in breeding programmes. It has been proved that RAPD can be suitable and efficient tool for genetic characterization of many plant species including oilseed rape (Hu el al., 1999).

\section{References}

Cartea, M. E., P. Soengas, A. Picoaga and A. Ordas. 2005. Relationships among Brassica napus (L). germplasm from Spain and great Britain as determined by RAPD markers. Genetic Resources and Crop Evolution 52: 655-662.

Hu, J., G. Li, D. Struss, and C.F. Quiros. 1999. SCAR and RAPD markers associated with 18-carbon fatty acids in rape seed, Brassica napus. Plant Breed. 118: 145-150.

Jain, A., S.Bhatia, S.S. Banga, S. Prakash and M. Lakshmikumaran. 1994. Potential use of random amplified polymorphic DNA (RAPD) technique to study the genetic diversity in Indian mustard (Brassica juncea) and its relationship to heterosis. Theor. Appl. Genet. 88: 116-122.

Nei, M. 1972. Genetic distance between populations. American Naturalist 106: 283-292. 
Nei, M. 1973. Analysis of gene diversity in subdivided populations. Proceedings of the National Academy of Sciences 70: 332 1-3323.

Rabbani. M. A., A. Iwabuchi, Y. Murakmi, T. Suzuki and K. Takayanagi. 1998. Genetic diversity in mustard (Brassica juncea L.) germplasm from Pakistan as determined by RAPDs. Euphytica 103: 235-242.

Vos, P., R. Hogers, M. Bleeker, M. Reijans, D.L.T.van, M. Hornes, A. Freijters,J. Pot, J. Peleman, M. Kuiper and M. Zabeau. 1995. AFLP a new technique for DNA fingerprinting. Nucleic Acids Res. 23: 4407-4414.

Williams, J.G.K., M.K. Hanafey, J.A. Rafalski and S.V. Tingey. 1993. Genetic analysis using random amplified polymorphic DNA markers. Methods Enzymology 218: 705740.

Yarnell, S.H. 1956. Cytogenetics of Vegetable Crops. Bot. Rev. 22: 81-166.

Yeh, F.C., R.C. Yang, T.B.J. I3oyle, Z.H. Ye and J.X. Mao. 1999. POPGENE, the userfriendly shareware for population genetic analysis. Molecualr Biology and Biotechnology Centre, University of Alberta, Canada. 